\title{
"EN LA GLORIA EN DONDE EL LENGUAJE ES VER". ALGUNAS NOTAS SOBRE LAS TÉCNICAS DE VISUALIZACIÓN EN EL SERMÓN BARROCO
}

\author{
PaOlo TANGANELli \\ Università di Ferrara
}

1. La predicación aurisecular eleva a una perfección inaudita muchas de las técnicas de visualización que ya se aplicaban en la época medieval. No es ninguna exageración afirmar que en el XVII se asiste a un verdadero 'giro visual', que, por supuesto, no afecta solo al sermón, sino a todos los géneros de escritura literaria. ${ }^{1}$ Por este motivo, aunque suene banal, huelga repetir que el anhelo ecfrástico, la firme voluntad de fabricar imágenes verbales, lo es todo en el ámbito de la predicación barroca: con este imperativo nace un sermón nuevo, ya completamente desligado de la prédica escolástica, y bajo este signo termina su periplo, bien entrado el XVIII,

${ }_{1}$ Cf. F. Rodríguez de la Flor, Giro visual. Decadencias de la lecto-escritura y primacía de la imagen, Salamanca, Delirio, 2009; Id., Imago. La cultura visual y figurativa del Barroco, Madrid, Abada, 2009. 
cuando el padre Isla parodia los conceptos predicables y la actio teatral de los oradores barrocos con su Fray Gerundio de Campazas.

En efecto, todo en la predicación barroca se juega en el terreno inestable de la ekfrasis, porque -como apuntaba el jesuita José de Ormaza- «[1]a descripción es hoy no solo figura, sino todo el pasto y baraja de los predicadores». ${ }^{2}$

La arquitectura de las oraciones sacras que examina Hilary Dansey Smith ${ }^{3}$ es una mera abstracción, un esqueleto que explica bien poco de lo que ocurre en el Siglo de Oro; porque, cada vez más, los discursos de los predicadores auriseculares no respetan la tradicional subdivisión de las viejas retóricas, alternando de la forma más variada secuencias, más o menos desordenadas, de reparos, paradojas, enigmas y -antes que ninguna otra cosa- descripciones, jeroglíficos, emblemas. En una palabra, imágenes.

Pero dicha proliferación de imágenes (descritas y, en ciertos casos, también expuestas), este constante predicar a los ojos, como justamente lo define Giuseppina Ledda, ${ }^{4}$ no debe engañar a nadie $y$, sobre todo, no puede inducirnos a pensar que las artes praedicandi y los sermonarios del XVII brindan un escenario uniforme, donde rétores y predicadores (alcanzado un acuerdo general y a priori sobre la utilidad de las 'máquinas de la descripción', es decir, sobre la absoluta preeminencia de los códigos visuales) se limitarían a entregarse a una vana y cansina imagolatría. Al contrario, precisamente en torno a las modalidades de configuración de las imagines mentis ante diferentes auditorios se desarrolla un intenso debate. Desde luego, en esta ocasión podré rememorar tan solo algunas de estas sutiles tecnologías de representación mental inducidas por las sabias palabras o los gestos calculados de los oradores barrocos.

Un ansia excesiva de esquematización empobrece cualquier perspectiva hermenéutica; pero tal vez se podría sostener que en la predicación hispánica del XVII hay al menos dos técnicas fundamentales y complementarias de visualización: una que hace hincapié principalmente en la teatralización del sermón, es decir, en un lenguaje evidente acompañado por una actio y una escenografía apropiadas; y otra que aboga, en cambio, por los conceptuosos itinerarios de la visión (como dijo Enrica Cancelliere de Góngora), ${ }^{5}$ por figuras emblemáticas o enigmáticas cuyo desciframiento resulta a menudo dificultoso.

2 J. de Ormaza [Gonzalo Pérez de Ledesma], Censura de la Elocuencia, ed. de G. Ledda y V. Stagno, Madrid, El Crotalón, 1985, p. 119.

3 H. D. Smith, Preaching in the Spanish Golden Age. A Study of some Preachers of the Reign of Philip III, Oxford / London etc., Oxford University Press, 1978.

4 G. Ledda, «Predicar a los ojos», Edad de Oro, 8 (1989), pp. 129-142.

5 E. Cancelliere, Góngora. Percorsi della visione, Palermo, Flaccovio, 1990. 
"En la gloria en donde el lenguaje es ver". Algunas notas sobre las técnicas de visualización en el sermón barroco

Estas dos estrategias, que burdamente separaré en mi apresurada reconstrucción, se podrían relacionar con las diferentes circunstancias de la prédica, empezando por la ocasión (no es lo mismo una oración fúnebre que un sermón de cuaresma) y, aún más, por el tipo de auditorio que podía presenciar a la celebración (el público selecto de la corte o de las universidades, el inculto de las misiones o el mixto de las catedrales).

Delante de un auditorio rudo, manifiestamente inferior, como sucedía en la predicación misionera de las llamadas indias de acá (se puede pensar en las Batuecas, en los pueblos gallegos o en la Alpujarra), el orador eclesiástico debía privilegiar una gestualidad patética, además de la hipotiposis de una res truculenta, visualizada en todos sus detalles a través de un verbum poco engalanado, si bien sustentado por un sólido armazón retórico de interrogaciones, exclamaciones o sermocinationes. ${ }^{6}$ Como es obvio, detrás de esta combinación late aún el connubio entre enargeia y movere que procede del más ilustre legado retórico latino y que permea también la composición de lugar ignaciana. Un lenguaje llano y evidente que casa perfectamente con una actio espectacular.

Al contrario, ante un destinatario culto, a la altura -por así decir- del predicador más ducho, como el acicalado auditorio cortesano, ${ }^{7}$ se solían escoger imágenes enigmáticas o descripciones amenas de corte hermogénico junto con un lenguaje pródigo de cultismos, anteponiendo el delectare al movere y optando por una visualización compleja, múltiple y dotada, incluso, de una estructura anamórfica o emblemática.

2. Creo que en el ancho abanico de la predicación barroca se podrían colocar en un extremo las representaciones del sermón teatral y en otro las imágenes literarias de la prédica conceptuosa. Para tratar un argumento tan dilatado como el de las técnicas de visualización en el sermón barroco, elegiré el atajo de esta simple contraposición, sin tomar en cuenta ni la evolución de la predicación aurisecular, ni las aportaciones de algunos de los autores más significativos (como Hortensio Félix Paravicino, Jerónimo de Florencia, Manuel de Guerra y Ribera, etc.). Pero este atajo (el dualismo elemental entre prédica teatral y sermón conceptuoso) puede hacer alarde al menos de un importante punto de anclaje histórico: me refiero, por supuesto, a la disputa

\footnotetext{
6 Sobre la audaz experimentación de los misioneros jesuitas ante auditorios rurales, cf. B. Majorana, «Varios afectos y varias especies sensibles: la predicación de los jesuitas misioneros en las zonas rurales italianas (siglos XVII-XVIII)», en L. Gentilli y R. Londero (eds.), Emocionar escribiendo. Teatralidad y géneros literarios en la España áurea, Iberoamericana-Vervuert, Madrid-Frankfurt am Main, 2011, pp. 217-237 (p. 220); Id., «Missionarius / Concionator. Note sulla predicazione dei gesuiti nelle campagne (XVII-XVIII secolo)», Aevum, LXXIII-3 (1999), pp. 807-829.

7 Cf. O. H. Green, «Se acicalaron los auditorios: An Aspect of the Spanish Literary Baroque», The Literary Mind of Medieval \& Renaissance Spain, Lexington, The University of Kentucky, 1970, pp. 124-132.
} 
entre Ormaza y Céspedes, acaso la querella crucial en el ámbito de las artes praedicandi áureas. ${ }^{8}$

Entre los varios frentes de batalla que abren estos dos jesuitas (el joven Ormaza y el viejo Céspedes), uno de los más significativos afecta precisamente a estas formas encontradas de visualización. Porque Ormaza es el portaestandarte del sermón conceptuoso y de unas visualidades caleidoscópicas, mientras que Céspedes defiende la tradicional techné que combina evidentia verbal y actio teatral.

3. La Censura de la elocuencia de Ormaza, publicada en 1648 (el mismo año en que aparece también la segunda y definitiva edición de la Agudeza y arte de ingenio de Gracián) es la primera retórica jesuita publicada en España que sostiene la apremiante necesidad de revitalizar con una inyección de puro conceptismo la compositio loci ignaciana, despojándola de su constitutivo patetismo. Para Ormaza «no basta que la descripción sea con buenas palabras y amplificaciones, deve ser briosa en el modo de dezir y conceptuosa». ${ }^{9}$ El placer de la descripción nace, se podría glosar, no tanto de la elegancia del estilo, cuanto de las agudezas (ante todo de concepto) con las que logra maravillar a los oyentes más cultos y capturar su atención; por esta razón, Ormaza condena las típicas descripciones de los sermonarios, que, siendo tan previsibles, no procuran un auténtico deleite. Esta censura la explica perfectamente Mercedes Blanco, cuyas acertadas palabras es preciso recordar:

Un público que se precia de refinado, instruido y maduro, tendrá por «agravio» que le juzguen desprovisto de «vulgarísimas noticias» y accesible a pueriles procedimientos de despertar curiosidad, y mirará por lo tanto con irritación este arte de contar, sostenido por los recursos de la actio, por la entonación y la gesticulación. El desdén de Ormaza por la narración de pasos de la Escritura, y especialmente por las historias del Antiguo Testamento, las historias de Abraham, Jacob o David, posiblemente responda al gusto de amplias minorías capaces de leer libros, que rechaza por insulsa y vulgar la linealidad sencilla y solemne de estos sagrados, pero arcaicos, cuentos. ${ }^{10}$

\footnotetext{
8 L. López Santos, «La oratoria sagrada en el Seiscientos. Un libro inédito del P. Valentín de Céspedes», Revista de Filología Española, 30 (1946), pp. 353-368; G. Ledda, "Antiguos y nuevos predicadores: una polemica sull'oratoria sacra del ‘600», en B. Periñán y G. Guazzelli (eds.), Symbolae Pisanae. Studi in onore di Guido Mancini, Pisa, Giardini Editori, 1989, pp. 311-325; F. Cerdan y J. E. Laplana Gil, «Introducción», en Valentín de Céspedes, Trece por docena, s.l., Presses Universitaires du Mirail [Anejos del Criticón], 1998, pp. 7-73; G. Ledda, «Introducción», en J. de Ormaza, op. cit., pp. 9-36; M. Blanco, «Humanismo rezagado frente a difícil modernidad. Al margen de la polémica Ormaza-Céspedes sobre la oratoria sagrada», en F. Cerdan (ed.), La oratoria sagrada en el Siglo de Oro, Criticón, 84-85 (2002), pp. 123-144.

9 J. de Ormaza, op. cit., p. 122.

10 M. Blanco, op. cit., p. 135.
} 
"En la gloria en donde el lenguaje es ver". Algunas notas sobre las técnicas de visualización en el sermón barroco

Ormaza condena no solo estas descripciones narrativas, basadas en los habituales lugares bíblicos, ${ }^{11}$ sino también las estereotipadas pinturas que constituyen los morceaux de bravoure de todos los predicadores:

Aquí se encrespa algo más la Eloquencia, quedando mui vfano el que en çarças, carros, tempestades y naues de Tyro, engüeca más las velas. De suyo más energía y gala tiene aquesto que la simple narración de vn sucesso; pero ya esto se ha vulgarizado tanto que, sin grande y nueuo realze, no lo deuen vsar los más limados. $^{12}$

El joven rétor solo elogia a los espíritus ingeniosos que, alejándose de la Sagrada Escritura y de estas descripciones sobadas, se atreven a fabricar pinturas imaginarias: «Dexando, pues, ya aquestas más vulgares, passo a otras que tienen más inventiua y las podemos llamar imaginarias, en que se pintan no como fueron las cosas, sino como más a nuestro modo las podemos delinear». ${ }^{13}$

A decir verdad, este tratadista no ofrece nunca una definición clara de lo que sería una pintura imaginaria; sin embargo, examinado sus ejemplos se podría argüir que la pintura imaginaria se construye a partir de una «semejanza conceptuosa» (como diría Gracián): utiliza un símil ingenioso, planteando a menudo una especie de enigma o de emblema. El mecanismo es relativamente simple: la pintura imaginaria sustituye la descripción que el público se espera con otra, más o menos alejada, que acaba por convertirse, de este modo, en una especie de símbolo o emblema de la descriptio suprimida. Es una técnica anamórfica, ya que presupone una doble mirada: se observa una imagen en primera plana para ver al final otra.

En consecuencia, la pintura imaginaria no trata de hacer ver una res con todo detalle (su finalidad primordial ya no es la enargeia); más bien evoca de forma simultánea esbozos de imágenes diversas y los liga de forma ingeniosa. Es una aguda aleación, un concepto dilatado, casi -como apuntaba hace un momento- un trampantojo anamórfico; y por esta razón no concierne solo a la elocutio y a la dispositio, sino que involucra a fondo la misma inventio.

Si Ormaza juzga particularmente adecuadas para este empleo sobre todo las descripciones que deben representar los «mayores misterios al pueblo», ${ }^{14}$ es porque dichas res dejan un margen superior a la inventiva del predicador con respecto a los manidos lugares historiales de la Biblia, autorizándolo a echar manos de todos los recursos del ornatus difficilis para lograr ofrecer siquiera un pálido reflejo del arte divino

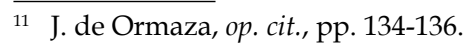

12 Ibidem, p. 134.

13 Ibidem.

14 Ibidem, p. 135.
} 
(Deus pictor). Al fin y al cabo, si «en la gloria [...] el lenguaje es ver» como afirmaba Velasco, ${ }^{15}$ se podría sostener que Ormaza construye sus refinados dispositivos ecfrásticos precisamente para que los auditorios instruidos se vayan aproximando, ya desde esta ladera, a esa mirada metafísica.

4. Recordaré escuetamente cómo Ormaza describe dos misterios mayores: la Anunciación y el Ascenso de María.

En la evocación ormaziana de la Anunciación, que se inspira en un modelo paraviciniano, se presenta la imagen de un embajador plenipotenciario que, con un rico acompañamiento militar, desfila, a la vez, por las calles de una ciudad y entre los astros de la Vía Láctea. De este modo, Ormaza retrasa el encuentro entre la Virgen y el Arcángel Gabriel para introducir un fragmento descriptivo bastante común en la sermonística coeva (el tópico de las entradas triunfales del ejército), pero cuyo empleo no era previsible en este punto:

Embió Dios al Arcángel Gabriel con la mayor embaxada, despoblándose el Cielo por assistirla con el devido aparato. ¡Qué quexoso quedaría el Ángel, si alguno quedó allá arriba sin papel en el acompañamiento! Formaron, pues, desde el sitial de Dios al retrete de María, una calle de luz las lucidíssimas tropas de esquadrones volantes, en cuyos granados petos reverbera la Divinidad con más ardor que el Sol en los christales. Aqueste, pues, gran Pueblo de Príncipes hizo calle poblada, a uno y otro lado, de montes de diamantes de Espíritus al tope que, a porfía, unos entre otros, se assomavan a ver el que passava. ${ }^{16}$

Además, amplifica este fastuoso introitus con otros símiles, insertando nuevas pinturas dentro de la pintura principal. Así, por ejemplo, los ángeles-espectadores, que en el fragmento inicial se habían convertido en «montes de diamantes», se vuelven, conforme al anterior «calle de luz», en la misma Vía Láctea atravesada por la estrella más luminosa, la del emisario divino:

Cuidado fue del Omnipotente el aparato de su Embaxador, que llevava no solo su poder, mas sus poderes, para el mayor desposorio. Iba, pues, passando esta sagrada exhalación por aquella vía láctea que formaron tantas amontonadas

15 «Si pudieramos en los sermones dar las cosas más a ver, que a oírlas, agradaran más los sermones Porque usamos de las vozes en lugar de las cosas, y mientras las palabras representan mejor las cosas que se dizen, causan más deleyte, porque parece que se ven, quando se oyen [...]. Pero mientras no estamos [sic] en la gloria en donde el lenguaje es ver, será fuerça que lo que intentamos acá dar a ver, lo signifiquemos con las palabras a los oýdos, para que deste sentido passe a la fantasma, y representación de las cosas, en donde estas deleitan, y no las palabras: con que mejor deleytará el Predicador que mejor representare con las palabras, y modo las cosas que dize dándolas a ver que el que las dize solo para que las oygan. Las palabras no deleitan, sino las cosas significadas por medio de las palabras; y assí quando se hazen pinturas, notaciones, y descripciones: se deven pintar tan a lo vivo, que se vean las cosas, y las palabras que no sirvan más que de sombras: porque mal se divisa la pintura, quando es más el follage; que lo que se representa.» (M. de Velasco, Arte de Sermones para Saber Hazerlos, y Predicarlos, Cádiz, por el Alférez Bartolomé Núñez de Castro, Impressor, y Mercader de Libros, s.d. [1677], pp. 210-211).

16 J. de Ormaza, op. cit., p. 135. 
"En la gloria en donde el lenguaje es ver".Algunas notas sobre las técnicas de visualización en el sermón barroco

estrellas, ninguna errante, aunque ninguna fixa, volando todas por acercarse más a su Señora María. ${ }^{17}$

Por supuesto, en esta pintura imaginaria se puede detectar la presencia también de algunas agudezas verbales (como la bisemia de «errante» y de «poder»); pero lo esencial es su arquitectura ingeniosa. El artificio conceptuoso teorizado por Gracián consistía «en una primorosa concordancia, en una armónica correlación entre dos o tres cognoscibles extremos». ${ }^{18}$ Del mismo modo, la pintura de Ormaza hace hincapié en una analogía recóndita o enigmática entre la típica descripción esperada, que es suprimida o retrasada, y la descripción imaginaria que la simboliza y, en parte o del todo, la reemplaza. Por esta razón, para pintar el Ascenso de María, Ormaza incluso llega a utilizar un emblema silente, la res picta del cedro:

El Cedro más altivo, que pretende ser columna del Firmamento, encumbrando tanto sus hojas que las confunde con las Estrellas la vista, asseguró a tanta altura firmeza en las raízes, con que baxa a unirse al centro de la tierra. Quando, más favorecido de influencias, trepa al Cielo produciendo una selva en cada rama, más reconocido a la tierra, la abraça en apretados ñudos de raízes. Desta suerte consigue vivir Cielo el que nació tierra; y assí una planta subiendo baxa y baxando sube. ¡O Ascenso, Emblema digno del que celebramos oi! Asciende María Santíssima más allá del Firmamento, démonos parabienes de que prendió en la tierra; que no subiera tan alta y tan crecida al Cielo, si no echara muchas raízes en el suelo. ${ }^{19}$

La pintura imaginaria domina la predicación culta también durante la época de Carlos II. En los sermonarios de Guerra y Ribera, por ejemplo, se encuentran a menudo sofisticadas descripciones que se podrían tildar de ormazianas. Pero esta técnica de visualización se complica cada vez más; y a menudo en la segunda mitad del siglo, en vez de una pintura imaginaria bien delineada, nos topamos con secuencias de semejanzas conceptuosas sin jerarquía, que el orador eclesiástico se limita a enunciar sin detenerse en ninguna, y que reflejan, más que la técnica ormaziana, la concepción del mundo simbólico y la espistemología analógica de Kircher, Tesauro o Picinelli.

Como ya he intentado explicar en otra ocasión, ${ }^{20}$ el Epítome de la elocuencia española de Artiga (retórica en verso publicada en 1692) tal vez sea el manual que manifiesta de la forma más nítida este estancamiento de la pintura imaginaria ormaziana. Ante la imposibilidad de inventar nuevas pinturas que sigan suscitando admiratio, Artiga propone una serie de esquemas amplificativos sin preocuparse de rellenarlos de manera adecuada. Su descripción de los Ángeles, por ejemplo, es un caleidoscopio

\footnotetext{
17 Ibidem.

18 Baltasar Gracián, Agudeza y arte de ingenio, ed. de E. Correa Calderón, Madrid, Castalia, 2001, I, p. 55.

19 J. de Ormaza, op. cit., p. 195.

20 P. Tanganelli, «La crisis de la oratoria sagrada entre los siglos XVII y XVIII. El Epítome de la elocuencia española de Artiga y los modelos descriptivos de la predicación gerundiana», Annali online di Ferrara Lettere, 1 (2008), pp. 124-138.
} 


\section{Paolo Tanganelli}

informe donde se superponen cuatro esquemas amplificativos diferentes (que remiten a otros tantos campos metafóricos: los cuatro elementos cósmicos, el locus amoenus edénico, los astros y la organización político-militar de un estado). Pero cada una de estas trazas equivale tan solo a una pintura imaginaria en potencia o, mejor, abortada, porque los nexos analógicos anunciados no se traducen en ninguna imagen perspicua.

5. Uno de los principales apologistas del sermón teatralizado es Valentín de Céspedes, nieto del Brocense, quien dedica varias secciones (llamadas azotes) de su Trece por docena al problema de las descripciones lícitas. Condena con dureza las deleitosas pinturas imaginarias de Ormaza y reivindica la utilidad de los lugares bíblicos por su patética evidencia:

De suerte, Señor mío, que referir la penitencia de un David, describiendo muy despacio cómo un rey poderoso y regalado se levanta a medianoche desnudo, se anega en lágrimas, se exhala en suspiros, se despedaza a golpes y postrado en la tierra clama al cielo con íntimos afectos del alma, acusando sus excesos y clamando por misericordia, ¿no moverá a los oyentes a llorar sus pecados? El pintar a un rey de Nínive cuando se arroja de su trono y, ajando y aun rompiendo sus vestiduras y reales insignias, se viste de un saco y cubre su cabeza de ceniza, ayunando y llorando continuamente, ¿no hará mella en las voluntades para que se rindan a las persuasiones de la palabra de Dios? [...] Ver obedecer a Abraham [...] ¿no nos moverá a que obedezcamos a Dios en las cosas tanto menos pesadas que nos manda? Ver la libertad santa con que Elías entra a hablar al rey Acab [...], ¿no exhorta al celo ardiente de la honra de Dios atropellando los respetos del mundo? ${ }^{21}$

No es casual que en este fragmento Céspedes pase de los verbos describir y pintar al verbo ver: el humanista defiende el nexo enargeia / movere que tanta importancia conserva todavía en la teoría descriptiva de Fray Luis de Granada y en la meditación ignaciana.

Agrega, además, que la visión mental del espectador tiene que ser reforzada mediante una hábil recitación. Si Fray Luis de Granada ${ }^{22}$ solo había apuntado la relación entre la actio del predicador y la hipotiposis, el detractor de las pinturas imaginarias explica que el predicador (definido «representante a lo divino») tiene que pintar a la vez con la palabra y con el gesto.

A Fray Francisco de Lerma vi en el Hospital de Zaragoza desquijarar el león de

Sansón, y otra vez dejar la capa de Josef en mano de la gitana, y otra colgada la víbora de la muñeca del brazo de San Pablo, todo con tanta bizarría y decencia que

21 V. de Céspedes, op. cit., p. 84 [Azote I, 8].

22 «Entre las figuras adecuadas para producir 'visiones', ' poner las cosas delante de los ojos', recomienda el 'razonamiento fingido', o sermocinatio, la concesión de la palabra apta a las personas evocadas, a los seres ausentes, a cosas inanimadas, procedimiento que ofrece la ventaja irrenunciable de una buena actio [...]. La palabra que pinta, habla por tanto a la vista imaginativa creando 'visiones', se dirige a los sentidos (vista, oído) con la actio.» (G. Ledda, «Práctica y arte concionandi en la Retórica de fray Luis de Granada», Documentos A. Fray Luis de Granada: una visión espiritual y estética de la armonía del Universo, 4, septiembre 1992, pp. 108-114; p. 111). 
"En la gloria en donde el lenguaje es ver". Algunas notas sobre las técnicas de visualización en el sermón barroco

todo el auditorio fue una estupenda admiración, y afirmaban que habían visto el león destrozado, la capa suelta, y culebreando la víbora. A otro vi después en el mismo puesto pintar el sacrificio de Abraham y otro día el derribar las colunas de Sansón con tan singular propiedad, viveza y gracia, que prorrumpieron los oyentes en aplausos gritados, siendo necesario parar hasta que se sosegase el tumulto. ${ }^{23}$

El autor del Trece por docena, aunque evoque y celebre esta destreza de actor (supongo que para mostrar la víbora enroscada a la muñeca sería preciso un movimiento ondulatorio del brazo), sostiene a la vez que estas técnicas teatrales ya habrían caído en desuso en la segunda parte del XVII:

Alcánzaseme [...] que me podrá decir alguno que si bien lo que se ha discurrido tiene fuerza contra el Censurador, pero que absolutamente no es dotrina a propósito para los tiempos que ya corren, porque así las descripciones, buen siglo hayan, como las representaciones, Dios las perdone, ya pasaron su carrera, y así agora descansan en paz. No se embarazan en eso los predicadores cortesanos, sino que hacen todo el convite de su sermón de dos o tres punticos de mucho garbo, adornados de unos lugares y concepticos picados y picantes que concluyan presto y den en la nuca del agrado con estilico muy conciso y misterioso... ${ }^{24}$

En realidad, dichas afirmaciones necesitan ser matizadas. El obsoleto sermón teatral al que Céspedes alude era una conción válida para todos los tipos de público, que, al igual que la comedia nueva, incluía distintos niveles estilísticos.

Pero no es verdad que el sermón teatralizado se hubiese extinguido en esos años: sin duda había dejado la corte y acaso se iba retirando también de las iglesias metropolitanas, si bien justo en la segunda mitad del XVII encontró un terreno sumamente fértil en la predicación misionera interna.

6. Para examinar la oratoria sacra aurisecular es preciso distinguir entre las ideas de 'crisis' y 'decadencia': estas categorías conceptuales, aunque limítrofes, no deben confundirse.

Céspedes y Ormaza reaccionan de forma antitética ante una crisis que origina, en última instancia, el inexorable proceso de especialización del sermón barroco: los predicadores escriben para auditorios cada vez más diferenciados; y sobre todo la predicación culta reclama, en consecuencia, una autonomía creciente. Ormaza celebra esta especialización (de hecho, piensa solo en un público de letrados), mientras que Céspedes se opone a ella (como demuestran sus ejemplos, sigue evocando todavía el público mixto de las grandes iglesias metropolitanas).

${ }_{23}$ V. de Céspedes, op. cit., p. 93 [Azote II, 7]; cf. op. cit., p. 95 [Azote II, 11].

${ }_{24}$ Ibidem, p. 100 [Azote II, 23]. 
La verdadera decadencia llega después de esta crisis y de la polémica entre dichos rétores, es decir, al final de este proceso de especialización en función del destinatario: el sermón barroco se empantana en el momento en que ya no logra fabricar verdaderas imagines mentis.

Lo he dicho al principio y lo repito: la predicación barroca debe su fuerza a una rica imaginería. Tanto las imágenes evidentes y patéticas del sermón teatral de Céspedes cuanto las conceptuosas y anamórficas de Ormaza podían ser eficaces en sus respectivos contextos de recepción. La decadencia se inicia cuando los epígonos de ambas escuelas renuncian a seguir predicando a los ojos.

En la vertiente de la prédica conceptuosa, el paso de Ormaza a Artiga conlleva una desintegración de la visión: en la colección de pinturas imitables que cierra el Epítome de la elocuencia española apenas se enuncian cadenas de 'concepticos' sin enfocar ya ninguna imagen; en cierto modo, todo ya está previsto, y Artiga crea involuntariamente un efecto poliantea que traiciona la idea original de pintura imaginaria.

En el mismo lapso de tiempo se refuerza y afina la actio en los sermonarios de misiones internas, que se empiezan a publicar alrededor de 1650 y prosiguen hasta las primeras décadas del XVIII; pero también en estas prédicas sumamente teatrales se deteriora, al final del siglo, la técnica de imprimir imágenes mentales en la memoria de los auditorios populares.

7. El misionero barroco en las indias de acá era un actor que debía interpretar constantemente su papel desde el momento en que entraba en el pueblo o en la ciudad donde se le enviaba a predicar. ${ }^{25}$ Todo en su conducta estaba reglamentado. A veces las congregaciones de misioneros incluso establecían lo que podía comer en las ventas donde se alojaba, cuando más se exponía a miradas curiosas e indiscretas.

Los tratadistas que relatan la actividad de los misioneros asumen este talante teatral. Martín de la Naja, ${ }^{26}$ por ejemplo, habla abiertamente de «santas invenciones» y de «espectáculos» para definir estas actuaciones, en las cuales los momentos más

25 «En las Ciudades, Villas, y Lugares donde llegaren a hazer Missión, para ser recibidos con más veneración, y exemplo, entren a pie, con sus váculos...» (Congregación de Ministros del Salvador (Madrid), Instrucción que se da a los Missioneros de la Congregación de Sacerdotes indignos Ministros del Salvador del Mundo, sitta en su Iglesia, y Casa desta Villa de Madrid, para dar forma, y uniformidad a los Exercicios que dichos Ministros acostumbran practicar en las Missiones que por Instituto de dicha Congregación se hazen en los lugares deste Arçobispado de Toledo, los Otoños y Primaveras... según las Constituciones, y Acuerdos que dicha Congregación tiene hechos, s.l., s.n., s.d. [1684], fol. 1v).

26 M. de la Naja, El missionero perfecto, deducido de la vida virtudes, predicación y missiones del venerable, y apostólico predicador, Padre Gerónimo López, de la Compañía de Iesús. Con una práctica muy cumplida, de la perfecta forma de azer Missiones, con fruto de las Almas, conforme el estilo, que en ellas guardava el mismo V. P. y otros Missioneros insignes..., En Zaragoça, por Pasqual Bueno, 1678, pp. 563-575. 
"En la gloria en donde el lenguaje es ver". Algunas notas sobre las técnicas de visualización en el sermón barroco teatrales quizá fueran el coloquio con la calavera o la evocación de las penas del infierno.

El empleo de una oportuna escenografía era fundamental y por esta razón el misionero debía viajar con una serie de objetos imprescindibles. ${ }^{27}$ Por ejemplo, para conferir más verosimilitud a sus topografías infernales los misioneros solían mostrar un cuadro que retrataba un alma condenada. El padre Gavarri escribe sobre este lienzo, que era una especie de mini-telón, en un manual publicado en 1679:

Procure también llevar el Padre Missionero un quadro, que de una parte esté pintado un feo condenado, y de la otra una alma en el Cielo, y enseñarlas al Pueblo en una Plaça, y un día de fiesta, para que los de el campo las vean, explicándoles como el condenado está en el infierno, por no aver hecho penitencia, \&c. Y para hazer grande fruto con el condenado, pintarle en la cabeça un fiero dragón, como que se le come, y en la boca unas mordaças, y en las manos unas cadenas, y en el coraçón un sapo, y por todo el cuerpo, que tenga muchas llamas, y debaxo unos reales de a ocho pintados. ${ }^{28}$

La costumbre de describir, en el transcurso de la prédica, frescos o cuadros que el público podía contemplar, o incluso figuras conocidas que podía rememorar sin ningún esfuerzo, era muy antigua y muy difusa. San Bernardino de Siena es un auténtico maestro en este arte, ya que con su sermonario fabrica un extraordinario mapa de las pinturas de su ciudad. ${ }^{29} \mathrm{El}$ blanco de estas pseudo-ekfraseis era resemantizar imágenes familiares transformándolas en signos perdurables de amonestación e invitación a la penitencia, para que la urbe terrenal reflejara cada vez mejor la ciudad celestial. ${ }^{30}$

El programa iconográfico del misionero barroco es mucho más humilde: entre otras razones porque el cuadro que utiliza no es un elemento externo del que se aprovecha el sermón, sino algo que forma parte ab initio de la misma prédica, el ineludible complemento de un verbum que, sin este lienzo, podría resultar peligrosamente carente e ineficaz.

27 Cf. L. Gentilli, «En la escena del mundo: la performance de predicadores y misioneros en la España del siglo XVII», en L. Gentilli y R. Londero (eds.), Emocionar escribiendo. Teatralidad y géneros literarios en la España áurea, pp. 197-215.

28 J. Gavarri, Instrucciones predicables, y morales, no comunes, que deben saber los Padres Predicadores, y Confessores principiantes, y en especial los Missioneros Apostólicos, Madrid, Antonio Gonçález de Reyes, 1679 , fol. 15r.

29 Cf. L. Bolzoni, La rete delle immagini. Predicazione in volgare dalle origini a Bernardino da Siena, Torino, Einaudi, 2002, pp. 167-198; «...no es cosa nueva valerse los Predicadores zelosos, y varones Apostólicos de estas santas invenciones, pues sabemos, que S. Patricio, S. Bernardo, y S. Bernardino de Sena, usaron de ellas en su Predicación...» (M. de la Naja, op. cit., p. 564).

${ }^{30}$ Cf. F. Rodríguez de la Flor, Barroco. Representación e ideología en el mundo hispánico (1580-1680), Madrid, Cátedra, 2002, pp. 123-160. 
Es revelador el empleo del verbo pintar en el fragmento citado de Gavarri; en efecto, sería preciso preguntarse quién pinta de verdad, si la mano que prepara el cuadro en el monasterio antes de la misión, o la tétrica elocuencia con la cual el misionero intenta animarla desde el centro de una plaza o desde el altar de una lóbrega iglesia rural. Por supuesto, ambos elementos se necesitan para existir, ya que la verdadera pintura no es ni el cuadro ni la ekfrasis predicatoria, sino el reflejo mental de ambos. El lienzo y su descripción solo son instrumentos para grabar una imagen indeleble en la memoria de los oyentes.

Aunque parezca que en el ámbito misionero la enargeia conserva toda su fuerza aliada a la actio teatral, no siempre es así, según documenta El oyente preservado, y fortalecido, un sermonario de Miguel Ángel Pascual que vio la luz en 1698.

No hay dudas de que, para Pascual, la actio es la dimensión más relevante de la prédica misionera. Todos sus sermones comienzan con una acotación, titulada Advertencia, en la que se indica qué objetos escénicos deberá utilizar el misionero; además, a lo largo del texto figuran numerosas glosas marginales que señalan el momento exacto en el cual se debe mostrar cada uno de ellos y, en ciertos casos, también se definen las modalidades de ostensión. Los objetos escénicos se utilizan por lo menos dos veces en un mismo sermón, y casi siempre al final de cada una de las dos pláticas que lo componen (como si fuera una especie de epílogo icástico, al objeto escénico se encomienda la tarea de compendiar la prédica). De vez en cuando en la Advertencia se otorgan otros consejos, como en el «Sermón de la Cárcel del Infierno, para el día nueve de Missión», donde se lee:

Este Día, en que se predica de el Infierno, ha de disponer el Predicador, que se ponga a vista de el Auditorio, el Retrato de aquella Alma condenada, que se sacó el quarto Día, o pendiente de el Púlpito, o a un lado; pero de manera que se vea bien; para que pueda mejor considerarse, y de quando en quando, requiriéndolo la Materia, se bolverá a ella, y hará algún Coloquio, o conciliará su consideración con algunas Exclamaciones. ${ }^{31}$

Sin embargo, Pascual, que cuida con tanto esmero la colocación del cuadro y los gestos del predicador, a menudo se olvida de animar verbalmente la pintura. Como todos los misioneros, Pascual multiplica las invitaciones hacia el auditorio para que contemple la calavera, el cuadro del alma condenada, el crucifijo o las cadenas: con una serie de imperativos construye un 'marco' lingüístico y guía la mirada de los fieles hacia la construcción de una imago mentis transcendente. Pero sus órdenes tajantes

\footnotetext{
31 M. Á. Pascual, El oyente preservado, y fortalecido, en una Missión practicada..., Parte Segunda, Valencia, por Diego de Vega, 1698, VII, p. 1. Otras glosas son más lacónicas, como la «Advertencia» del «Sermón de el pecado mortal, para el día XI. de Missión»: «Si vino bien en el otro Sermón, que se predicó de el Pecado, sacar el Retrato de un Pecador al Púlpito, mucho mejor en este, que se predica de su esclavitud...» (ibidem, p. 77).
} 
"En la gloria en donde el lenguaje es ver".Algunas notas sobre las técnicas de visualización en el sermón barroco están desligadas de cualquier detalle concreto verdaderamente significativo. De este modo describe el cuadro del alma en la prédica:

Levantad, fieles, vuestros ojos, y fijadlos en este espetáculo. Mirad esta cabeza pelada. Mirad estas cadenas. Mirad esta S y este clavo. ¿No es señal? ¿No significa, que este pecador es un vil esclavo y está sujeto a una pesada e infame servidumbre? El tenerle de la mano y atado este demonio, ¿no significa que es esclavo suyo y de todos aquellos que tienen su poder, que son el mundo con todos sus haberes, gustos, honras y riquezas? Y asimismo, de la carne con todos sus allegados, que son sus apetitos y pasiones. ${ }^{32}$

Los dos imperativos iniciales («Levantad [...] vuestros ojos», «fijadlos») anuncian el inicio del proceso de visualización. Luego, la anáfora trimembre de Mirad forma una suerte de retículo que debería delimitar y sustentar la hipotiposis. La mirada de los oyentes explora el lienzo: «Mirad esta cabeza pelada. Mirad estas cadenas. Mirad esta S y este clavo». Sin embargo, lo que se muestra y explica verbalmente es muy poco, casi nada.

En la sucesiva descripción de este objeto Pascual crea un retículo anafórico incluso más complicado, donde la enargeia se une ya al movere; sin embargo, la descripción sigue siendo sumamente caliginosa:

Ea, levantad los ojos y aparejad lágrimas. Llorad, hijos mios. Llorad esta desdicha. Mirad este rostro feo y denegrido: «Denigrata est super carbones». Mirad estas cadenas. Considerad estas heridas y, sobre todo, poned vuestra atención en este señor que la tiene presa y de quien es vil esclava. ¿No ves a este que está a la mano derecha muy ufano con la presa y muy alegre? ¿Quién dirás que es? Este es el Demonio, el dueño a quien sirves. A este has dado gusto. Mira qué hermoso dueño tienes. Mira qué lindo. ¿No ves este palo que tiene en su mano? ¿Qué dirás que significa? La crueldad de su dominio [...]. Vuelve los ojos hacia estotro lado. ¿No ves a este bello joven muy lloroso y triste? ¿Quién dirás que es? El Ángel de la Guarda; a quien tú has despreciado y por eso está a la mano izquierda. ${ }^{33}$

En esta jaula de imperativos y anáforas, que orientan la mirada del público e intentan encauzar su reacción emotiva, ya no se describe nada. Si las antiguas Imagines de Filóstrato creaban la ilusión de contemplar unos cuadros posiblemente imaginarios que nunca se pintaron, aquí la presencia de un lienzo real aniquila paulatinamente todo esfuerzo de proyección verbal. El catálogo de los detalles dilucidados es insuficiente y aproximativo: «rostro feo y denegrido», «estas cadenas», «estas heridas», «la tiene presa», «este que está a la mano derecha [...] es el Demonio», «este palo que tiene en su mano», «este bello joven muy lloroso y triste [...] es [...] [e]l Ángel de la Guarda», «está a la mano izquierda». El ángel de la guarda es un mancebo lógicamente entristecido,

\footnotetext{
32 Ibidem, p. 107. La cursiva es mía.

33 Ibidem, p. 138. La cursiva es mía.
} 
mientras que la crueldad del demonio parece concentrarse tan solo en el «palo» que empuña. ¿Sería esta una hipotiposis?

8. Tanto las pinturas imaginarias de Ormaza ante los auditorios acicalados, cuanto las descripciones evidentes y teatrales de Céspedes ante públicos mixtos, eran instrumentos poderosos, capaces de forjar imagines mentis persuasivas o curiosas.

La decadencia de estos sofisticados dispositivos, que merecen un estudio más articulado del que he bosquejado aquí, empieza mucho después de esta disputa, en el momento en que van desapareciendo los detalles descriptivos de los modelos conceptuosos cortesanos y de las representaciones teatrales de los misioneros. Finalmente despojada de sus miríficas imágenes, la predicación tardobarroca pierde su esencia y se reduce, en el crepúsculo del siglo, a verborrea insensata o a gesticulación ridícula. Es este el panorama desolado que contempla la generación del padre Isla. Y, desafortunadamente, es esta la visión tópica que ha llegado hasta nuestros días de ese mundo perdido. 